\title{
Evaluation of Partial Replacement of Fish Meal with Lablab Purpureus Seed Meal on the Performance of Broilers
}

\author{
Kuzegera David Isabirye ${ }^{1, *}$, James Higenyi ${ }^{2}$, Elizabeth Kizito ${ }^{1}$ and Esau Galukande ${ }^{3}$ \\ ${ }^{1}$ Uganda Christian University ${ }^{2}$ Ministry of Agriculture Animal Industry and Fisheries ${ }^{3}$ Kampala \\ Capital City Authority \\ *Corresponding author.
}

\begin{abstract}
This study investigated the use of Lablab purpureus seed meal as protein ingredient replacing fish meal. One hundred eighty (180) broiler chicks were used in a complete randomized block design. Three treatments were used; A (fish meal, as control), B (30\% fish replacement by roasted lablab with enzyme supplement) and C (45\% fish replacement by roasted lablab with enzyme supplement). The parameters studied were; feed consumption, weight gain and feed conversion ratio (FCR). Results revealed significant $(\mathrm{P}<0.05)$ differences in feed intake, weight gain and feed conversion ratio among the treatments. Throughout the study, chicks registered high feed intake on diet $\mathrm{C}$ and $\mathrm{A}$ while that in group $\mathrm{B}$ reported the least. Average weight gains were high for group $\mathrm{C}$ and $\mathrm{A}$ while group $\mathrm{B}$ registered the lowest. Feed conversion ration; lowest for group $\mathrm{C}$ and highest in group B. Therefore, a better performance of broilers is enhanced consumption by high intake of feed, high weight gains and low FCR, $45 \%$ dietary fish meal can be replaced by Lablab purpureus seed meal with enzyme supplement in a compounded broiler finisher.
\end{abstract}

Keywords: Optimization, Alternative protein, Feed technology.

\section{Introduction}

Globally, poultry production is the fastest growing livestock enterprise driven by a combination of factors including demand for animal protein, urbanization, shift in consumption patterns and rapid population growth (Rushton, 2009; FAO, 2010). Additionally, Chicken is very important for household incomes, food security and nutrition (animal protein and micronutrients) contributing 33\% of global meat supply, second per capita consumption after pork $(36 \%)$ (USDA, 2021). The demand for animal protein by the growing world population is steadily increasing particularly in developing countries (OECD and Food and Agriculture Organization for United Nations, 2010; Ravindran, 2013).

In Uganda, poultry, cattle and pig are increasingly promoted to enhance production and productivity of animal and animal products. Although, per capita consumption of poultry meat is still low at $13.4 \mathrm{~kg}$ compared to the world's estimated at $45.3 \mathrm{~kg}$ by 2030 (FAO, 2019; USAID, 2010). Largely (75-90\%), family poultry contributes to total poultry meat consumed (FAO, 
2008; USAID, 2010, Komi and Nakimbugwe, 2017). Unfortunately, the extensive system is constrained by low level of genetics, management and lack of application of technology and innovations resulting into reduced quality and quantity of poultry meat; increasingly the gap between supply and demand is expected to continue (Ravindran, 2013). Moreover, there is limited investment in broiler production business (MAAIF and UBOS, 2009, 2010).

Formulation of balanced diets is critical in the profitability of the broiler production. Compounded feed contributes $60-80 \%$ of the cost of production, largely $(70 \%)$ attributed to rising prices of fish meal as protein ingredients which results into expensive formulated feeds (Davis, 2015; Makinde and Olayinka, 2015; Komi and Nakimbugwe, 2017, Ssepuuya et al., 2017). This in turn limits feed availability (quality and quantity) and consequently, hinders efficient animal production and productivity (MAAIF, 2010). In Uganda, the prices of fishmeal doubled in the last decade; from UGX 2,000/kg (USD 1.12) in 2005 to UGX 3,500/kg (USD 1.0) in 2017 and still increasing with little prospect of receding (Gordon and Ssebisubi, 2012; Katende, 2017; Komi and Nakimbugwe, 2017). This has made initial investment in the enterprise expensive, limiting new entrants into broiler production business and expansion of the existing farms. As a cope up strategy, most (53.3\%) poultry farmers have resorted to formulating homemade feeds with the majority of protein dietary requirement supplied by plant protein sources and a limited part of animal protein sources (Komi and Nakimbugwe, 2017). The commonly used plants protein sources in feed formulation include; soy bean, palm kernel cake, cotton seed cake and sunflower meal, among others. Although, largely $(90 \%)$ soybean meal is preferably used as plant protein ingredient in poultry diets because of its amino acid profile, unfortunately it's becoming scarce and costly (FAOSTAT, 2012, Ravindran, 2013).

By implication, optimization of alternative protein source ingredients which are less expensive, abundant and easily accessible in formulation of least cost compounded poultry feeds is necessary to realize sustainable and profitable broiler production (Leeson and summers, 2009, Van Huis et al., 2013). Insects in form of larvae (maggots) and adult flies have increasingly been used as alternative sources of proteins ingredients in production of livestock feeds (Maurer et al., 2015; Makinde and Olayinka, 2015, Van Huis et al., 2013). Plant protein sources that have been used in replacement of fish meal during formulation of poultry feeds include, ground nut cakes, velvet beans, pigeon pea and lablab beans, among others (Abeke et al., 2008). One of the key plants that can be of good use for poultry feed formulation as a partial replacement for fish meal is Lablab purpureus. The plant belongs to the family of legumes, Fabaceae with scientific name Lablab purpureus and is locally known as Hyacinth bean seeds. It is largely used in livestock feeding by many cattle farmers. The seed can be made available as part of the ingredients for making animal feeds. The use of Lablab purpureus seed as livestock feed has limited applicability in spite of the fact it provides a high protein source of $23-25.4 \%$, metabolisable energy (ME) ranges from $347.4-353.7 \mathrm{kcal} / \mathrm{kg}$, rich in essential amino acids like lysine, and methionine, among others (Soetan and Fafuuso, 2010; Kilonzi et al., 2017). Studies that have attempted to replace fish meal by Lablab purpureus seed at levels of $5-30 \%$ and have registered poor performance in broilers (Abeke et al., 2008). Currently in Uganda, Lablab purpureus seed is mostly utilized in ruminant nutrition with limited applicability in poultry feed production and as human food (Bawa et al., 2003). Moreover, Lablab purpureus is a single most legume plant largely grown as local forage legume under integrated sustainable agriculture for ruminant nutrition, nitrogen fixing and soil improvement, and erosion control. Thus, its availability and can be sustainability used in poultry feed formulation. This study evaluated the partial replacement of fish meal with Lablab purpureus seeds meal on the performance of finishing broilers. 


\section{Materials and Methods}

The experimental study was conducted in a poultry experimental house at Kyanja Agriculture Resource Centre, situated at coordinates $0.4015076{ }^{\circ} \mathrm{N}$ and $32.5933198{ }^{\circ} \mathrm{E}$ in Kampala district for a period of six weeks. A completely randomized design comprising of three experimental treatments replicated three times was used. The three experimental treatments were: $1, \mathrm{~A}(0 \%$ fish replacement by lablab seed meal, control), 2, B (30\% fish meal replacement by lablab seed meal with enzyme supplement) and 3, C (45\% fish replacement by lablab seed meal with enzyme supplement). Lablab seed was roasted at $100^{\circ} \mathrm{C}$ for 30 minutes before grinding it into seed meal to remove anti-nutritional factors (Abeke et al., 2008). A total of 180 experimental units (unsex commercial broiler chicks-Ross breed) were randomly allocated to three replicates each with 60 birds. Treatments A was commercial broiler finisher feed used as a control, B and $\mathrm{C}$ were formulated using computer methods based on recommended nutrient requirements (NRC, 1994). The birds were given feed and water adlibitum.

Representative samples of the experimental diets were taken for laboratory analysis to ascertain their chemical composition reference to standard nutrient composition of broiler diet (FAO, 2012). Data was collected during the finishing phase after brooder (three weeks) and adaptation phases (one week). Subsequent sampling for collect data was done at weekly interval.

Data was transcribed into the Micro-soft Excel (Version 2013) for sorting, editing and filtering. Later, it was exported to STATA Microsoft ware for descriptive and inferential analyses. Descriptive analysis generated graphs and charts. Analysis of Variance (ANOVA) generated means, variances and standard means, and significantly different means separated by Duncan's Multiple Range Test at 5\% level of significance.

\section{Results}

The results of laboratory analysis of the nutrient composition of the experimental diets are shown in Table 1.

Table 1: Chemical composition of the experimental diets

\begin{tabular}{lccc}
\hline Variables & \multicolumn{3}{c}{ Experimental treatments } \\
\cline { 2 - 4 } & $\mathbf{A}$ & $\mathbf{B}$ & $\mathbf{C}$ \\
$\mathrm{DM}$ & 95.98 & 92.63 & 94.78 \\
$\mathrm{EE}$ & 1.46 & 1.20 & 1.48 \\
$\mathrm{CP}$ & 19.60 & 17.60 & 19.20 \\
$\mathrm{CF}$ & 9.07 & 8.05 & 8.05 \\
$\mathrm{Ash}$ & 6.31 & 5.22 & 6.12 \\
$\mathrm{NFE}$ & 55.54 & 49.53 & 51.42 \\
Lysine & 1.10 & 1.10 & 1.10 \\
Methionine & 0.45 & 0.35 & 0.45 \\
$\mathrm{Ca} \%$ & 1.20 & 1.20 & 1.20 \\
$\mathrm{P} \%$ & 0.64 & 0.54 & 0.54 \\
$\mathrm{ME}(\mathrm{Kcal} / \mathrm{kg})$ & 3102.27 & 3100.10 & 3101.26 \\
\hline
\end{tabular}

DM (dry matter), EE (ether extract), CP (crude protein), CF (crude fibre), NFE (nitrogen free extract), Ca \%( calcium percentage), $\mathrm{P} \%$ (phosphorus percentage), ME (metabolizable energy). 
The findings indicate that the specific energy levels of the control experimental diets (A) and the formulated (B \& C) were consistent with recommended standard nutrient composition ration for feeding broilers. Further, the results showed that feed intake of broilers on different experimental diets varied significantly $(\mathrm{P}<0.05)$ with a higher average feed intake of experimental diet $\mathrm{C}$ throughout 28-49 days (Table 2).

Table 2. Average feed intake of broilers (g/day) fed on experimental diets

\begin{tabular}{llll}
\hline Experimental Treatment & $\mathbf{2 8 - 3 5}$ days & $\mathbf{3 6 - 4 2}$ days & $\mathbf{4 2 - 4 9}$ days \\
\hline A0\% & $80.5^{\mathrm{b}}$ & $102.9^{\mathrm{b}}$ & $125^{\mathrm{b}}$ \\
B $30 \%$ & $68^{\mathrm{a}}$ & $97^{\mathrm{a}}$ & $123^{\mathrm{a}}$ \\
C $45 \%$ & $84.5^{\mathrm{c}}$ & $107^{\mathrm{c}}$ & $128^{\mathrm{c}}$ \\
s.e.d & 0.01 & 0.01 & 0.01 \\
l.s.d & 0.02 & 0.02 & 0.01 \\
CV \% & 1.5 & 1.1 & 0.5 \\
F pr. & 0.001 & 0.001 & 0.001
\end{tabular}

Means with similar letters in a column are not significantly different at $\mathrm{p} \leq 0.05$ based on the Duncan's Multiple Range Test.

Similarly, the study explored the performance of birds in terms of average daily weight gains and feed conversion ratios. The results revealed increase in mean daily weight gain during the experimental period. Treatment $\mathrm{C}$ expressed the highest average daily weight gain throughout the 28-49 days' period with maximum of 100.1g in 42-49 days; followed by A at $90.1 \mathrm{~g}$ and B with the least average daily weight gain at $80.3 \mathrm{~g}$ (Table3). The variation in average daily weight gains were significant $(\mathrm{p}<0.05)$.

Table 3. Average daily weight gains of broiler birds fed on experimental diets

\begin{tabular}{llll}
\hline Experimental Treatment & $\mathbf{2 8 - 3 5}$ days & $\mathbf{3 6 - 4 2}$ days & $\mathbf{4 2 - 4 9}$ days \\
\hline A0\% & $65.4^{\mathrm{ab}}$ & $79.6^{\mathrm{ab}}$ & $90.1^{\mathrm{ab}}$ \\
B30\% & $46.9^{\mathrm{a}}$ & $62.8^{\mathrm{a}}$ & $80.3^{\mathrm{a}}$ \\
C45\% & $88.3^{\mathrm{b}}$ & $96.3^{\mathrm{b}}$ & $100.1^{\mathrm{b}}$ \\
s.e.d & 0.01 & 0.01 & 0.01 \\
l.s.d & 0.01 & 0.01 & 0.02 \\
CV \% & 30.7 & 20.3 & 33.3 \\
$F$ pr. & 0.001 & 0.001 & 0.34 \\
\hline
\end{tabular}

Means with similar letters in a column are not significantly different at $p \leq 0.05$ based on the Duncan's Multiple Range Test.

Regarding the feed conversion ratios (FCR) of broiler feed on experimental diets. The results indicated increasingly trend in FCR as birds aged. However, of all the diets, $\mathrm{C}$ expressed the best feed conversion ratios followed by $\mathrm{A}$ and least $\mathrm{B}$. More importantly, the variations in FCR were significant $(\mathrm{P}<0.05)$ (Table 4$)$. 
Table 4. Feed conversion rate of broilers fed on the experimental diets

\begin{tabular}{llll}
\hline Experimental Treatment & $\mathbf{2 8 - 3 5}$ days & $\mathbf{3 6 - 4 2}$ days & $\mathbf{4 2 - 4 9}$ days \\
\hline A $0 \%$ & $1.23^{\mathrm{ab}}$ & $1.29^{\mathrm{ab}}$ & $1.39^{\mathrm{ab}}$ \\
B $30 \%$ & $1.44^{\mathrm{b}}$ & $1.55^{\mathrm{b}}$ & $1.53^{\mathrm{b}}$ \\
C45\% & $0.96^{\mathrm{a}}$ & $1.11^{\mathrm{a}}$ & $1.27^{\mathrm{a}}$ \\
s.e.d & 3.50 & 2.56 & 4.79 \\
1.s.d & 7.19 & 5.26 & 9.83 \\
CV $\%$ & 29.2 & 21.3 & 34.7 \\
$F$ pr. & 0.015 & 0.010 & 0.51 \\
\hline
\end{tabular}

Means with similar letters in a column are not significantly different at $\mathrm{p} \leq 0.05$ based on the Duncan's Multiple Range Test.

\section{Discussion}

There has been an ever-raising cost of poultry feeds in Uganda because of expensive protein ingredients especially fish. This has curtailed investments in the poultry sector, thus impacting on the vulnerable small-scale holders particularly around the urban and peri-urban areas. These largely depend on poultry enterprises as income generating enterprises and source of cheap animal protein. Notwithstanding, there is rising demand and competition on use of silver fish for human consumption and in animal feed. Investigating the potential of alternative protein ingredients to replace fish as animal protein source ingredients is the only desirable intervention now to promote sustainable commercial broiler production. This study is the first of its kind in Uganda to explore the use of Lablab purpureus seed meal as an alternative protein ingredient replacing fish (silver fish) in formulating compounded poultry feeds (broiler finisher meal).

Generally, the results have revealed good performance with enhanced consumption of feed, high weight gains and low FCR at 45\% replacement of fish by Lablab purpureus seed meal. The results obtained showed higher feed intake and weight gains with low feed conversion ratio in broiler chicks. These findings were in agreement with the study by Elamin et al. (2013), who reported significant $(\mathrm{P}>0.05)$ effect of lablab diets on weight gains and feed conversion ratio.

On the contrary, the result were inconsistent with the report by Abeke et al. (2008), who noted a significant $(\mathrm{P}<0.05)$ reduction in weight gains, feed intake and feed efficiency of broilers fed on compounded feed with increased level of Lablab purpureus seeds meal. Similar observations were noted in another study by Okeke et. al. (2003). The explanations for the observed variations are associated with lablab seed processing methods used. Inadequate processing of the Lablab seed fails to completely remove the anti- nutritional factors which are responsible for poor palatability and consequently, decrease feed intake and weight gains. This is supported by Bawa et al. (2003a), who re-affirmed that phytic acid and tannin contents of lablab seed are very resistant to heat treatment and substantial amount remains on heat treatments.

Another observation by Abeke et al. (2008) and Rasha and Abdel (2007), emphasized that proper processing of the Lablab purpureus seeds meal effectively reduces the anti-nutritional factors to enable full utilization of nutrients by the birds for better performance. This is because seed roasting at $100^{\circ} \mathrm{C}$ for 30 minutes reduces inherent anti-nutritional factors $(76 \%$ destruction of anti-trypsin and phytic acid), boiling breaks trypsin inhibitors and cooking water dissolves the toxic cryogenic glycoside which improves taste, palatability and aroma of the formulated diet (Rasha and Abdel, 2007). 
Furthermore, the study exhibited lower feed conversion ratio for experimental diets of $45 \%$ replacement of fish by a leguminous Lablab purpureus seed meal. This concurred with study by Amaefule and Onwudike (2000), who reported better food conversion ratio in broilers, fed well on roasted pigeon pea and lablab beans meals. Generally, this validates the acceptable view that processing by roasting, cooking and boiling reduces the bio-chemicals (anti-nutritional factors) in the raw form of the legume which affect bioavailability and utilization of nutrients in the digestive system of the bird.

\section{Conclusion}

This experimental study has established that $45 \%$ of dietary fish meal can be replaced by Lablab purpureus seed meal with enzymes. This conclusion is premised on the improved higher feed intake which translated into increasingly higher average weight gains with impressive low FCR. Therefore, poultry producers should be encouraged to use Lablab purpureus seed meal enhanced with enzyme supplement as an alternative protein source ingredient for production of broiler value added feed (broiler finisher). It is recommended that further studies on serology and histological changes due to optimization of poultry feed mix with Lablab purpureus, and other processing methods; soaking, cooking and boiling and complete replacement of fish (100\%) by Lablab purpureus seed meal be conducted.

\section{Acknowledgement}

The authors would like to appreciate the Department of Agricultural and Biological Sciences, Uganda Christian University for their support and guidance. We are strongly indebted to Kyanja Agriculture Resource Centre for the support.

\section{References}

Abeke F.O., Ogundipe S.O., Sekoni A.A., Adeyinka I.A., Oni O.O., Abeke A. and Dafwang I.I. 2008. Effect of Dietary Levels of Cooked Lablab purpureus Beans on the Performance of Broiler Chickens. American Journal of Food Technology, 3: 42-49. DOI: 10.3923/ajft.2008.42.49 https://scialert.net/abstract/?doi=ajft.2008.42.49

Amaefule, K.U. and Onwudike, O.C. 2000. Evaluation of processing methods of pigeon pea seeds (Cajanus cajan) as protein source for broiler starter. Journal of Sustainable Agriculture and Environment, 2: 134-138.

Bawa, G.S., Tegbe, T.S.B., Ogundipe, S.O, Dafwang, I.I. and Abu, E.A. 2003. The effect of duration of cooking of lablab seeds on the level of some anti- nutritional factors. Proceedings of the 28th Annual Conference NSAP, (NSAP'03), Ibadan, Nigeria, pp. 213-215.

Bawa, G.S., Tegbe, T.S.B., Ogundipe, S.O., Dafwang, I.I. and Abu, E.A. 2003a. The effect of feeding graded dietary levels of lablab seeds as replacement of soybeans on performance characteristics of young pigs. Proceedings of the 28th Annual Conference NSAP, Ibadan, Nigeria, pp. 230-232.Davis, D.A., 2015. Feed and feeding practices in aquaculture. Wood head Publishing, Cambridge, UK, pp. 404. 
Elamin, K.M, Malik, H.E.E and Dousa, B., 2013. Effect of Feeding Processed Hyacinth Bean (lablab purpureus) Seeds on Broiler Chick Performance https://www.researchgate.net/publication/255947233

FAO.2008. Poultry Sector Country Review. Uganda. FAO Animal Production and Health Division www.fao.org/avianflu//en/farmingsystems.html.

FAO.2009. The State of Food and Agriculture. http://www.fao.org/catalog/inter-e.htm.

FAO.2010. Poultry Meat and Eggs, agribusiness hand book. www.eastagri.org.

FAO.2019. Africa Sustainable Livestock 2050: The future of livestock in Uganda, opportunities and challenges in the face of uncertainty.

FAOSTAT.2012. Production quantity of soybeans 2010. URL http://faostat.fao.org/site/ $567 /$ DesktopDefault.aspx? PageID=567\#ancor.

Gordon, D.V. and Ssebisubi, M. 2012. Vertical and horizontal integration in the Ugandan fish supply chain: measuring for feedback effects to fishermen. Aquaculture Economics and Management 19: 29-50.

Katende, C. 2017. Feeds and quality, major factors in varying egg prices. Daily Monitor, Kampala, Uganda. Available at: http://tinyurl.com/y7bva929.

Kilonzi, S., Makokha, O, Kenji, M. G.2017. Physical characteristics, proximate composition and anti-nutritional factors in grains of lablab bean (Lablab purpureus) genotypes from Kenya. Journal of Applied Biosciences 114: 11289-11298

Komi, F and Nakimbugwe, D.2017. Insfeed - Integrating Insects in poultry and fish feed in Kenya and Uganda.

Leeson and summer .2009. Commercial poultry nutrition, $3^{\text {rd }}$ edition

MAAIF .2010. Agriculture for Food and Income Security. Agriculture Sector Development Strategy and Investment plan: 2010/11-2014/15

MAAIF and UBOS. 2009. The national livestock census: A summary report of the national livestock census. Uganda Bureau of Statistics, May, 1-34 https://doi.org/10.5267/j.msl.2012.06.001

Makinde and Olayinka, J. 2015. Maggot Meal: A Sustainable Protein Source for Livestock

Maurer, V. Holinger, M., Amsler, Z., Früh, B., Wohlfahrt, J., Stamer, A.., Leiber, F.2015. Replacement of soybean cake by Hermetia illucens meal in diets for layers

OECD and Food and Agriculture Organization of the United Nations, 2010. Meat. OECDFAO Agricultural Outlook 2010. OECD Publishing. Pp. 147-158.

Rasha, M. S. and Abdel, K.A. 2007. Effect of Dietary Hyacinth bean (lablab purpureus) on broiler chicks' performance. Research Journal of Agriculture and Biological science, 3(5):494-497.

Ravindran, V. 2013. Poultry feed availability and nutrition in developing countries. Poultry development review: 60-63.

Rushton, J. 2009. The economics of animal health and production. Oxford and Cambridge (Mass), CAB International National Research Council. (1994). Nutrient requirement of poultry, $9^{\text {th }}$ revised edition, Washington, DC, National Academy press.

Soetan, O.K., and Fafunso, M.A. 2010. Studies on the proximate and mineral composition of three varieties of lablab beans (lablab purpureus).International journal of applied agricultural research, volume 5 number 3 (2010) pp. 291-300

Ssepuuya, G., Mukisa, I.M. and Nakimbugwe, D. 2017. Nutritional composition, quality, and shelf stability of processed Ruspolia nitidula (edible grasshoppers). Food Science and Nutrition 5: 103-112.

UBOS, 2010. Uganda census of agriculture 2008/2009, Volume IV: Crop Area and Production Report. Retrieved from www.ubos.org 
USAID, 2010. Partnership for Safe poultry in Kenya (PSPK) Program. Value chain analysis of poultry in Uganda

Van Huis, A., Itterbeeck, V., Klunder, H., Esther, M., Halloran, A., Muir, G. and Vantomme, P. 2013. Edible insects: future prospects for food and feed security. FAO Forestry Paper 171. FAO, Rome. 